BOTANICA

ISSN 2538-8657

2020, 26(2): 160-169

\title{
LICHENS AND ALLIED FUNGI FROM THE PRAVIRŠULIO TYRELIS STATE NATURE RESERVE (CENTRAL LITHUANIA)
}

\author{
Aleksandr Yatsyna ${ }^{1}$, Vaclovas Stukonis ${ }^{2 *}$, Bernd Gliwa ${ }^{3}$ \\ ${ }^{1}$ V.F. Kuprevich Institute of Experimental Botany, Akademichnaya Str. 27, 220072 Minsk, Belarus \\ ${ }^{2}$ Institute of Agriculture, Lithuanian Research Centre for Agriculture and Forestry, Instituto Av. 1, 58344 Akade- \\ mija, Lithuania \\ ${ }^{3}$ Sargeliai 7, 60443 Sargeliai, Lithuania \\ *Corresponding author. E-mail: vaclovas.stukonis@lammc.lt
}

\begin{abstract}
Yatsyna A., Stukonis V., Gliwa B., 2020: Lichens and allied fungi from the Praviršulio Tyrelis State Nature Reserve (Central Lithuania). - Botanica 26(2): 160-169.

The paper presents the results of the inventory of lichen-forming, lichenicolous and allied saprobic fungi from the Praviršulio Tyrelis State Nature Reserve. A total of 199 species were recorded, including 183 lichens, eight lichenicolous and eight non-lichenised saprobic fungi. Four lichenised species (Micarea pseudomicrococca, Parmelia serrana, Sclerophora amabilis and Thelocarpon laureri) were reported new to Lithuania. Three protected species, Cetrelia olivetorum, Cladonia parasitica and Hypotrachyna revoluta, were also observed.
\end{abstract}

Keywords: biodiversity, bog, lichens, lichenicolous fungi, protected area.

\section{INTRODUCTION}

Praviršulio Tyrelis is a bog in Lithuania, where "Tyrelis" is a dialectal name for any open raised bog, and Praviršulis is the name of the lake inside the bog (GLiwA, 2008). In 1969, the bog with surrounding forests was declared a protected area. The protected area of Praviršulio Tyrelis covers 3316 ha. The bog is one of the ten largest bogs in Lithuania and the only one that remained natural and relatively undisturbed by peat mining in Central Lithuania. Later, the territory was included into the Natura 2000 network, both as Special Area of Conservation and Important Bird Area. The checklists for vascular plants with 446 species and mosses with 124 species have already been compiled (Stukonis, 2009, 2009a). This study provides a checklist of lichen-forming, lichenicolous and allied fungi from Praviršulio Tyrelis. Special attention was paid to indicator species for forest key habitats and protected species.

\section{MATERIALS AND METHODS}

\section{Plant material}

The material was collected in 2009-2019. Systematic research was carried out in 2018-2019 to check all available habitats and substrates. Lichens were identified following routine microscopic techniques. Sterile corticolous lichens such as Fuscidea, Lecidea, Lecidella, Lepraria and Ochrolechia, as well as some species of lichens from the genus $\mathrm{Ce}$ trelia and Cladonia were identified employing thin layer chromatography (ORANGE et al., 2001). Voucher specimens were deposited at the Herbarium of the Institute of Experimental Botany (MSK-L) and the Herbarium of the Institute of Botany (BILAS).

\section{Investigation sites}

The investigations were carried out at 19 sites of the Praviršulio Tyrelis State Nature Reserve.

1. Forest with many fallen trees, mainly Fraxinus 
excelsior $\mathrm{L}$. There were few old trees, among these a solitary old Quercus robur L. The undergrowth had many old Corylus avellana L. (visited in 2017 and 2018).

2. Overgrowing meadow with few old birch trees (70-80 years), younger trees Betula pendula Roth and Populus tremula L., and bushes Salix spp. and Frangula alnus Mill. (visited in 2009, 2014 and 2018).

3. Site of a former manor with remaining old trees Tilia cordata Mill., Acer platanoides L. and several Quercus robur. Orchard remnants with old Malus domestica Borkh. and Pyrus communis L. were also present. A foundation of natural stones was preserved (visited in 2009 and 2019).

4. Open raised bog with low-growing trees Pinus sylvestris L. 2-4 m high. In 2000, it was partly influenced by a fire in the bog (visited annually).

5. Alkaline fen with small trees Betula pendula and shrubs Salix rosmarinifolia L., Frangula alnus, Juniperus communis L. Dominant mosses: Drepanocladus cosonii (Schimp.) Loeske and Campyllum stelatum (Hedw.) J. Lange et C. O. E. Jens (visited annually).

6. Partially drained pine forest with Ledum palustre L., containing large amounts of deadwood and fallen trees (visited in 2015 and 2017).

7. Stones of different sizes collected in groups or scattered over an area of 20 by 60 meters within a plantation of Picea abies (L.) H. Katrst., planted on former agricultural land in 2005 (visited in 2009, 2018, 2019).

8. Dense plantation of Picea abies on former agricultural land, age of trees 15 years (visited in 2009 and 2018).

9. Power line and road. The adjacent forest consisted of relatively young trees of Betula pendula, Populus tremula, Picea abies and Salix caprea L. (visited in 2018 and 2019).

10. Deciduous swamp forest of Betula pubescens Ehrh. and Alnus glutinosa (L.) Gaertn. with an admixture of Picea abies. The trees were up to 90 years old. Dead trees and deadwood not abundant (visited in 2009 and 2019).

11. Forest on the island in the bog. A single giant oak (Quercus robur) was especially rich in lichens (visited in 2009, 2011 and 2018).

12. A part of the bog that had been prepared for peat excavation around the $1960 \mathrm{~s}$, but it was stopped shortly after. A dense net of drainage ditches was overgrown with Sphagnum spp. The dried areas between the channels with a predominance of Calluna vulgaris (L.) Hull and Ledum palustre (visited annually).

13. Forest island in the bog with dominant trees Populus tremula, Alnus incana, Betula pendula and Picea abies (visited in 2015 and 2016).

14. Wetland forest consisting of Betula spp., Alnus glutinosa, Picea abies and Pinus sylvestris visited in (2012 and 2019).

15. Wetland forest with dominant Alnus glutinosa mixed with Picea abies and Betula spp. The trees were up to 70-80 years old (visited in 2009).

16. Forest with dominant Populus tremula and Betula pendula, less commonly found trees were Fraxinus excelsior, Quercus robur, Ulmus glabra Huds. and Alnus incana (L.) Moench (visited in 2009, 2014 and 2018).

17. Bog pine forest with a dense layer of Ledum palustre and Vaccinium uliginosum L. in the ground cover. The forest near the ditch was drained (visited annually).

18. Bog pine forest after a massive fire in 2000 , characterised by a large number of charred trunks of Pinus sylvestris and shrubs Ledum palustre and Vaccinium uliginosum (visited in 2009 and 2019).

19. Old forest on the island with several old (more than 150 years) Picea abies. The ground cover was rich in Oxalis acetosella L. and spring ephemeroids (visited in 2009 and 2019).

\section{RESULTS}

A total of 199 species (comprising 183 lichens, eight lichenicolous and eight non-lichenised saprobic fungi) were recorded in Praviršulio Tyrelis. Four species were reported new to Lithuania: $M$. pseudomicrococca Launis \& Myllys, Parmelia serrana A. Crespo, M.C. Molina \& D. Hawksw., Thelocarpon laureri (Flot.) Nyl. and Sclerophora amabilis (Tibell) Tibell.

The list of the recorded species includes the site number and its local description. New to Lithuania species are typed in boldface; lichenicolous fungi are marked with "\#”; non-lichenised saprobic fungi are marked with "+". Nomenclature of lichenised and saprobic fungi follow Nordin et al. (2011), of lichenicolous fungi - LAwrey\& Diederich (2018). 


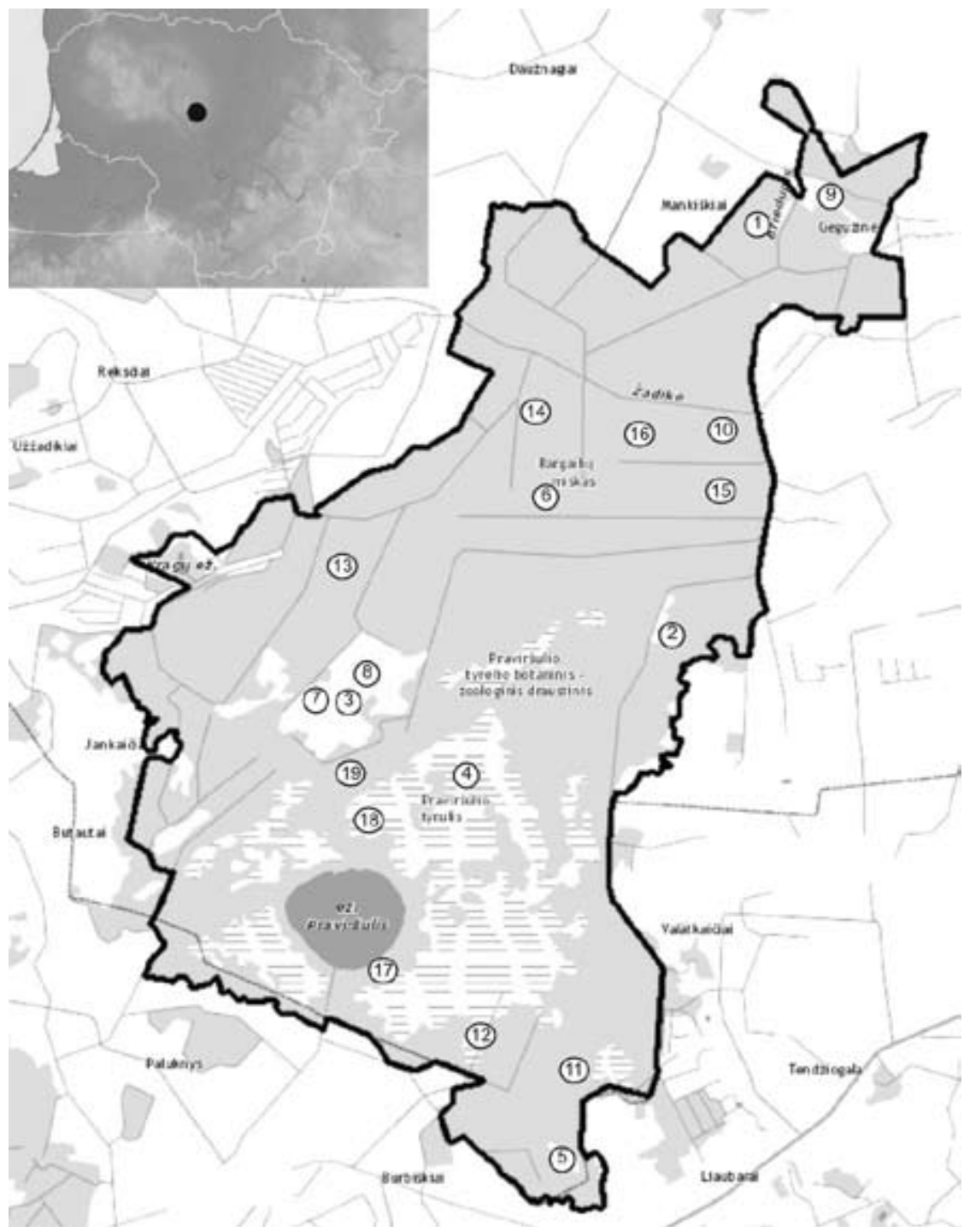

Fig. 1. The investigated sites of the Praviršulio Tyrelis State Nature Reserve. The numbers correspond to those given in the text

\section{List of species}

Absconditella lignicola Vězda \& Pišút - at site 17, on decaying wood of Pinus sylvestris.

Absconditella sphagnorum Vězda \& Poelt - at site 4, on dead Sphagnum spp. in the open raised bog.

Acarospora fuscata (Schrad.) Th.Fr. - at site 7, on siliceous stones.

Acrocordia gemmata (Ach.) A. Massal. - at sites 1, 13, 16, 19, on trunks of Populus tremula, rarely on trunks of Fraxinus excelsior and Ulmus glabra.

Alyxoria varia (Pers.) Ertz \& Tehler - at sites 1 and 3, on trunks of Acer platanoides, Fraxinus excelsior, Tilia cordata and Ulmus glabra.
Amandinea punctata (Hoffm.) Coppins \& Scheid. - at site 3, on trunks of Tilia cordata.

Anaptychia ciliaris (L.) Körb. - at sites 1, 13, 16 , on trunks of various deciduous trees, especially Populus tremula.

Arthonia dispersa (Schrad.) Nyl. - at sites 1 and 16, on trunks of Acer platanoides.

Arthonia radiata (Pers.) Ach. - at sites 1 and 16, on trunks of Corylus avellana.

Arthonia spadicea Leight. - at sites 10, 14, 15, on trunks of Alnus glutinosa.

Arthothelium ruanum (A. Massal.) Körb. - at site 1 , on trunks of Corylus avellana. 
Aspicilia cinerea (L.) Körb. - at site 2, on siliceous stones.

Athallia cerinella (Nyl.) Arup, Frödén \& Søchting - at sites 2 and 9, on branches of Populus tremula.

Athallia pyracea (Ach.) Arup, Frödén \& Søchting s. lat. - at site 2, on trunks of Populus tremula.

Bacidia arceutina (Ach.) Arnold - at site 1, on trunks of Acer platanoides.

Bacidia bagliettoana (A. Massal. \& De Not.) Jatta - at site 2, dead bryophytes in the soil.

Bacidia polychroa (Th.Fr.) Körb. - at site 1, on trunks of Fraxinus excelsior.

Bacidia rubella (Hoffm.) A. Massal. - at sites 1, $3,13,16$, on trunks and branches of various deciduous trees.

Bacidina sulphurella (Samp.) M.Hauck \& V. Wirth - at site 1, on decaying wood of Picea abies.

Biatora efflorescens (Hedl.) Räsänen - at site 13, on trunks of Populus tremula.

Biatora globulosa (Flörke) Fr. - at site 1, on trunks of Fraxinus excelsior.

Bryoria implexa (Hoffm.) Brodo \& D. Hawksw.at site 4, on trunks of Pinus sylvestris.

Buellia griseovirens (Turner \& Borrer ex Sm.) Almb. - at sites 10, 14, 15, on trunks of Alnus glutinosa.

Buellia schaereri De Not. - at site 3, on trunks of Tilia cordata.

Calicium glaucellum Ach. - at sites 4, 6, 17, 18, on wood of Pinus sylvestris.

Calicium viride Pers. - at site 11, on trunks of Quercus robur.

Calogaya decipiens (Arnold) Arup, Frödén \& Søchting - at site 3 , on stones, the foundation of the building.

Caloplaca cerina (Hedw.) Th.Fr. - at site 9, on trunks of Populus tremula.

Caloplaca saxicola (Hoffm.) Nordin - at site 3, on stones, the foundation of the building.

Candelariella aurella (Hoffm.) Zahlbr. - at site 9, on trunks of Populus tremula.

Candelariella coralliza (Nyl.) H. Magn. - at site 7, on stones.

Candelariella reflexa (Nyl.) Lettau - at site 3, on trunks of Acer platanoides.

Candelariella vitellina (Hoffm.) Müll.Arg. - at site 3 , on a wooden fence.
Candelariella xanthostigma (Ach.) Lettau - at site 3, on trunks of Malus domestica.

Carbonicola anthracophila (Nyl.) Bendiksby \& Timdal - at site 8, on charred wood of Pinus sylvestris.

Cetraria sepincola (Ehrh.) Ach. - at site 5, on the branches of Betula pendula.

Cetrelia olivetorum (Nyl.) W.L. Culb. \& C.F. Culb.at site 10 , on trunks of Rhamnus cathartica.

Chaenotheca brachypoda (Ach.) Tibell - at sites 1 and 11, on the wood of Picea abies.

Chaenotheca chlorella (Ach.) Müll.Arg. - at site 1, on the wood of Picea abies.

Chaenotheca chrysocephala (Turner ex Ach.) Th.Fr. - at sites 6, 7 12, 17, 18, on the wood of Pinus sylvestris.

Chaenotheca ferruginea (Turner \& Borrer) Mig. - at sites 6, 7, 12,17, 18, in forests with pine, on trunks of Pinus sylvestris.

Chaenotheca furfuracea (L.) Tibell - at sites 1, 19, on exposed roots of toppled Picea abies.

Chaenotheca laevigata Nádv. - at site 1, on trunks of Quercus robur.

Chaenotheca phaeocephala (Turner) Th.Fr. - at site 3 , on trunks of Tilia cordata.

Chaenotheca stemonea (Ach.) Müll.Arg. - at sites 11 and 13, on trunks of Picea abies.

Chaenotheca trichialis (Ach.) Th.Fr. - at sites 1 and 3, on trunks of Tilia cordata.

Chaenotheca xyloxena Nádv. - at sites 17 and 18, on the wood of Pinus sylvestris.

+Chaenothecopsis pusilla

A.F.W. Schmidt - at site 17, on the wood of Pinus sylvestris.

Cladonia arbuscula (Wallr.) Flot. - at sites 12 and 17 , on the soil.

Cladonia botrytes (K.G. Hagen) Willd. - at site 6, on decaying wood.

Cladonia cenotea (Ach.) Schaer. - at site 6, on decaying wood of Pinus sylvestris.

Cladonia chlorophaea (Flörke ex Sommerf.) Spreng. - at site 18, on the soil.

Cladonia ciliata Stirt. - at site 4, among mosses and on peat in the raised bog.

Cladonia coccifera (L.) Willd. - at site 12, among mosses.

Cladonia coniocraea (Flörke) Spreng. - at site 14, on trunks of Pinus sylvestris. 
Cladonia cornuta (L.) Hoffm. - at site 6, on the soil.

Cladonia digitata (L.) Hoffm. - at site 17, on decaying wood.

Cladonia fimbriata (L.) Fr. - at site 17 , on the soil.

Cladonia floerkeana (Fr.) Flörke - at site 6, on decaying wood.

Cladonia furcata (Huds.) Schrad. - at sites 4 and 12, among mosses.

Cladonia gracilis (L.) Willd. ssp. gracilis - at sites 4 and 12, among mosses.

Cladonia grayi G. Merr. ex Sandst. - at site 17, among mosses.

Cladonia macilenta Hoffm. - at site 17, on decaying wood.

Cladonia novochlorophaea (Sipman) Brodo \& Ahti - at site 14, on trunks of Alnus glutinosa.

Cladonia parasitica (Hoffm.) Hoffm. - at site 4, on decaying wood.

Cladonia pyxidata (L.) Hoffm. - at site 4, among mosses.

Cladonia rangiferina (L.) F.H. Wigg. - at sites 4 and 12 , among mosses and on peat in the raised bog.

Cladonia stygia (Fr.) Ruoss - at sites 4 and 12 sites, among mosses and on peat in the raised bog.

Cladonia subulata (L.) Weber ex F.H. Wigg. - at site 2, on the soil.

\#Clypeococcum hypocenomycis D. Hawksw. - at site 18, on thalli of Hypocenomyce scalaris.

Coenogonium pineti (Ach.) Lücking \& Lumbsch - at site 19, on trunks of Pinus sylvestris.

Evernia prunastri (L.) Ach. - at site 3, on trunks of Malus domestica.

Fellhanera bouteillei (Desm.) Vězda - at sites 8 and 9, on twigs and needles of Picea abies.

Fellhanera subtilis (Vězda) Diederich \& Sérus. at site 17, on branches of Vaccinium myrtillus.

Flavoplaca citrina (Hoffm.) Arup, Frödén \& Søchting - at site 3, brick wall, on masonry.

Fuscidea pusilla Tønsberg - at site 13, on trunks of Alnus incana.

Graphis scripta (L.) Ach. - at site 1, on trunks of Corylus avellana.

Gyalolechia flavorubescens (Huds.) Søchting, Frödén \& Arup - at site 2, on trunks of Populus tremula.

Hertelidea botryosa (Fr.) Printzen \& Kantvilas - at site 1, on wood of Picea abies.

\#Heterocephalacria physciacearum (Diederich)

Millanes \& Wedin - at site 3, on thalli of Physcia tenella.

Hypocenomyce scalaris (Ach.) M.Choisy - at site 18, on wood of Pinus sylvestris.

Hypogymnia physodes (L.) Nyl. - at sites 1, 2, 5, $8,9,10,11,14,17,18$, on deciduous and coniferous bark.

Hypogymnia tubulosa (Schaer.) Hav. - at site 12, on branches of Betula pendula.

Hypotrachyna revoluta (Flörke) Hale - at site 10, on branches of Picea abies.

\#Illosporiopsis christiansenii (B.L. Brady \& D. Hawksw.) D.Hawksw. - at site 9, on thalli of Physcia $\mathrm{sp.}$

Imshaugia aleurites (Ach.) S.L.F. Mey. - at site 4, on trunks of Pinus sylvestris.

Inoderma byssaceum (Weigel) Gray - at site 1, on trunks of Quercus robur.

Lecania croatica (Zahlbr.) Kotlov - at site 19, on trunks of Alnus incana.

Lecania cyrtella (Ach.) Th.Fr. - at site 2, on branches of Betula pendula.

Lecania naegelii (Hepp) Diederich \& van den Boom - at site 2, on branches of Populus tremula .

Lecania prasinoides Elenkin - at site 14, on exposed roots of toppled Picea abies.

Lecanora allophana Nyl. - at site 1, on trunks of Populus tremula.

Lecanora carpinea (L.) Vain. - at site 13, on trunks of Alnus incana.

Lecanora chlarotera Nyl. - at site 14, on trunks of Alnus glutinosa.

Lecanora norvegica Tønsberg - at site 4, on trunks of Pinus sylvestris.

Lecanora pulicaris (Pers.) Ach. - at site 13, on branches of Betula pendula.

Lecanora rupicola (L.) Zahlbr. - at site 7, on siliceous stones.

Lecanora saligna (Schrad.) Zahlbr. - at site 3, on a wooden fence.

Lecanora symmicta (Ach.) Ach. - at site 11, on trunks of Betula pubescens.

Lecanora varia (Hoffm.) Ach. - at site 11, on trunks of Betula pendula.

Lecidea nylanderi (Anzi) Th.Fr. - at site 6, on trunks of Betula pendula. 
Lecidella elaeochroma (Ach.) M.Choisy - at sites $1,3,9,16$, on trunks and branches of deciduous trees.

Lecidella flavosorediata (Vězda) Hertel \& Leuckert - at site 19, on trunks of Betula pendula.

Lepra albescens (Huds.) Hafellner - at site 3, on trunks of Acer platanoides.

Lepra amara (Ach.) Hafellner - at site 1, on trunks of Fraxinus excelsior.

Lepraria eburnea J.R. Laundon - at site 17, on trunks of Pinus sylvestris.

Lepraria elobata Tønsberg - at site 17, on trunks of Betula pendula.

Lepraria finkii (B.de Lesd.) R.C. Harris - at site 1, on trunks of Acer platanoides.

Lepraria incana (L.) Ach. - at site 19, on trunks of Picea abies.

Lepraria jackii Tønsberg - at site 17, on hummocks.

Lepraria neglecta (Nyl.) Lettau - at site 3, on siliceous stones.

+ Leptorhaphis epidermidis (Ach.) Th.Fr. - at site 2, on trunks of Betula pendula.

Lichenomphalia umbellifera (L.: Fr.) Redhead, Lutzoni, Moncalvo \& Vilgalys - at site 4, among mosses.

Melanelixia glabratula (Lamy) Sandler \& Arup at site 1, on trunks of Fraxinus excelsior.

Melanelixia subargentifera (Nyl.) O. Blanco, A. Crespo, Divakar, Essl., D. Hawksw. \& Lumbsch - at site 3, on trunks of Tilia cordata.

Melanohalea exasperatula (Nyl.) O. Blanco, A. Crespo, Divakar, Essl., D. Hawksw. \& Lumbsch at sites $1,2,3,6,10,17$, on trunks and branches of deciduous trees.

Melanohalea olivacea (L.) O. Blanco, A. Crespo, Divakar, Essl., D. Hawksw. \& Lumbsch - at site 13, on trunks of Betula pendula.

Micarea elachista (Körb.) Coppins \& R. Sant. at site 4, on decaying wood.

Micarea melaena (Nyl.) Hedl. - at site 14, on trunks of Pinus sylvestris.

Micarea misella (Nyl.) Hedl. - at site 17, on decaying wood of Pinus sylvestris.

Micarea peliocarpa (Anzi) Coppins \& R. Sant. at site 14, on trunks of Pinus sylvestris.

Micarea prasina Fr. - at site 17, on decaying wood of Pinus sylvestris.
Micarea pseudomicrococca Launis \& Myllys at site 13, on trunks of Pinus sylvestris.

+ Microcalicium disseminatum (Ach.) Vain. - at site 1, on trunks of Quercus robur.

Montanelia sorediata (Ach.) Divakar, A. Crespo, Wedin \& Essl. - at site 3, on siliceous stones.

\#Muellerella hospitans Stizenb. - at site 1, on apothecia of Bacidia rubella.

+ Mycocalicium subtile (Pers.) Szatala - at site 4, on decaying wood of Pinus sylvestris.

Myriolecis dispersa (Pers.) Śliwa, Zhao Xin \& Lumbsch - at site 9, on concrete.

Myriolecis hagenii (Ach.) Śliwa, Zhao Xin \& Lumbsch - at site 6, on trunks of Populus tremula.

+ Naetrocymbe punctiformis (Pers.) R.C. Harris at site 9, on trunks of Betula pendula.

Nephromopsis chlorophylla (Willd.) Divakar, A. Crespo \& Lumbsch - at site 13, on trunks of Betula pendula.

Ochrolechia alboflavescens (Wulfen) Zahlbr. - at site 10, on trunks of Pinus sylvestris.

Ochrolechia microstictoides Räsänen - at site 4, on trunks of Pinus sylvestris.

Parmelia serrana A. Crespo, M.C. Molina \& D. Hawksw. - at sites 10, 14, 15, on trunks of Alnus glutinosa.

Parmelia submontana Nádv. ex Hale - at site 2, on trunks of Salix cinerea.

Parmelia sulcata Taylor - at sites 1, 2, 3, 9, 10, $11,12,13,14,15,16,17$, on trunks and branches of deciduous trees.

Parmeliopsis ambigua (Wulfen) Nyl. - at site 18, on trunk of Pinus sylvestris.

Peltigera canina (L.) Willd. - at site 9, on the soil.

Peltigera didactyla (With.) J.R. Laundon - at site 9, on the soil.

Peltigera neckeri Hepp ex Müll.Arg. - at site 1, on wood of Acer platanoides and Quercus robur.

Peltigera praetextata (Flörke ex Sommerf.) Zopf - at site 1, on trunk of Fraxinus excelsior.

Phaeophyscia ciliata (Hoffm.) Moberg - at site 16, on the trunk of Populus tremula.

Phaeophyscia nigricans (Flörke) Moberg - at site 3, on the trunk of Tilia cordata.

Phaeophyscia orbicularis (Neck.) Moberg - at sites $1,9,13,15$, on trunks and branches of deciduous trees, on concrete and on siliceous stones. 
Phlyctis argena (Ach.) Flot. - at sites 1, 9, 10, 15, 16 , on trunks and branches of various trees.

Physcia adscendens H. Olivier - at sites 1, 9, 14, 15,16 , on trunks and branches of deciduous trees, on concrete.

Physcia aipolia (Ehrh. ex Humb.) Fürnr. - at site 1 , on trunks of Populus tremula.

Physcia caesia (Hoffm.) Fürnr. - at site 7, on siliceous stones.

Physcia dubia (Hoffm.) Lettau - at site 9, on siliceous stones.

Physcia stellaris (L.) Nyl. - at sites 1, 9, 14, 15, 16 , on branches of deciduous trees.

Physcia tenella (Scop.) DC. - at sites 1, 2, 3, 9, $10,14,16$, on branches of deciduous trees.

Physconia detersa (Nyl.) Poelt - at site 3, on trunks of Acer platanoides.

Physconia distorta (With.) J.R. Laundon - at site 13, on trunks of Populus tremula.

Physconia enteroxantha (Nyl.) Poelt - at site 3, on the trunk of Tilia cordata.

Placynthiella dasaea (Stirt.) Tønsberg - at site 4, on decaying wood Pinus sylvestris.

Placynthiella icmalea (Ach.) Coppins \& P. James - at site 17, on decaying wood.

Placynthiella oligotropha (J.R. Laundon) Coppins \& P. James - at site 17, on plant remnants.

Platismatia glauca (L.) W.L. Culb. \& C.F. Culb.at site 19, on trunks of Betula pendula.

Pleurosticta acetabulum (Neck.) Elix \& Lumbsch - at site 3, on trunks of Acer platanoides.

Polycauliona polycarpa (Hoffm.) Frödén, Arup \& Søchting - at site 3, on branches of Tilia cordata

Polycauliona ucrainica (S.Y. Kondr.) Frödén, Arup \& Søchting - at site 3, on trunks of Tilia cordata.

Protoparmeliopsis muralis (Schreb.) M.Choisy at site 7, on siliceous stones.

Pseudevernia furfuracea (L.) Zopf - at site 4, on trunks of Pinus sylvestris.

Pseudoschismatomma rufescens (Pers.) Ertz \& Tehler - at site 1, on trunks of Fraxinus excelsior.

Pycnora praestabilis (Nyl.) Hafellner - at site 17, on the wood of Pinus sylvestris.

Pycnora sorophora (Vain.) Hafellner - at site 17, on trunks of Pinus sylvestris.

Ramalina farinacea (L.) Ach. - at site 1, on trunks of Populus tremula.
Ramalina fastigiata (Pers.) Ach. - at site 3, on trunks of Acer platanoides.

Ramalina fraxinea (L.) Ach. - at site 1, on trunks of Fraxinus excelsior.

Ramalina pollinaria (Westr.) Ach. - at site 3, on trunks of Tilia cordata.

Reichlingia leopoldii Diederich et Scheid. - at site 1, on trunks of Fraxinus excelsior.

Rhizocarpon distinctum Th.Fr. - at site 7, on siliceous stones.

Ropalospora viridis (Tønsberg) Tønsberg - at site 1, on trunks of Corylus avellana.

+Sarea difformis (Fr.) Fr. - at site 1, on the resin of Picea abies.

+Sarea resinae (Fr.: Fr.) Kuntze - at site 1, on the resin of Picea abies.

Sclerophora amabilis (Tibell) Tibell - at site 11, on old solitary Quercus robur.

Scoliciosporum chlorococcum (Graewe ex Stenh.) Vězda - at site 2, on branches of Salix spp.

Scoliciosporum sarothamni (Vain.) Vězda - at site 1, on the trunk of Quercus robur.

+ Stenocybe pullatula (Ach.) Stein. - at sites 10, 14, 15, on branches of Alnus glutinosa.

\#Stigmidium microspilum (Körb.) D.Hawksw. at site 1, on thalli of Graphis scripta.

Thelocarpon laureri (Flot.) Nyl. - at site 17, on decaying wood.

Toniniopsis subincompta (Nyl.) Kistenich et al. at site 1, on wood of Acer platanoides.

Trapeliopsis flexuosa (Fr.) Coppins \& P. James at site 17 , on decaying wood.

Trapeliopsis granulosa (Hoffm.) Lumbsch - at site 12 , on the soil.

\#Tremella phaeophysciae Diederich \& M.S. Christ. - at site 9, on thalli of Physcia spp.

Usnea hirta (L.) Weber ex F.H. Wigg. - at sites 2, 4, 6, on trunks and dead branches of Pinus sylvestris and Picea abies.

Verrucaria muralis Ach. - at site 2, on clay tiles.

Verrucaria nigrescens Pers. - at site 2, on small stones and clay tiles.

\#Vouauxiella lichenicola (Linds.) Petr. \& Sydow - at site 2, on apothecia of Lecanora spp.

Vulpicida pinastri (Scop.) J.-E. Mattsson \& M.J. Lai - at sites 4 and 5, on trunks of Pinus Sylvestris, Juniperus communis and decaying wood.

Xanthomendoza fulva (Hoffm.) Søchting, 
Kärnefelt \& S.Y. Kondr. - at site 3, on trunks of Acer platanoides.

Xanthoparmelia conspersa (Ehrh. ex Ach.) Haleat site 7 , on siliceous stones.

Xanthoparmelia loxodes (Nyl.) O. Blanco, A. Crespo, Elix, D. Hawksw. \& Lumbsch - at site 7, on siliceous stones.

Xanthoparmelia pulla (Ach.) O. Blanco, A. Crespo, Elix, D. Hawksw. \& Lumbsch - at site 7, on siliceous stones.

Xanthoparmelia verruculifera (Nyl.) O. Blanco, A. Crespo, Elix, D. Hawksw. \& Lumbsch - at site 7, on siliceous stones.

Xanthoria parietina (L.) Th. Fr. - at sites 1, 2, 3, on trunks and branches of deciduous trees.

\#Xanthoriicola physciae (Kalchbr.) D.Hawksw. at site 3, on apothecia of Xanthoria parietina.

Xylopsora friesii (Ach.) Bendiksby \& Timdal - at site 18, on charred wood of Pinus sylvestris.

Zwackhia viridis (Ach.) Poetsch \& Schied. - at site 1, on trunks of Fraxinus excelsior.

\section{DISCUSSION}

Survey of lichens has not been done so far in the Praviršulio Tyrelis State Nature Reserve. In this study, we found 199 lichen species, and four of them were identified for the first time in Lithuania. Moreover, three species were recorded as extinct and endangered species in Lithuania. Quite similar results of lichen species diversity were obtained in the Kamanos State Nature Reserve, which is close by its size to Praviršulio Tyrelis (Motiejūnaite 2011). After all, a survey of local areas is significant to clarify the regularities of individual species. Even more, such survey leads to the discovery of new species and the identification of their distribution area in Europe.

Micarea pseudomicrococca is characterised by an olive-green granular thallus and small creamy-white or pale brownish apothecia that lack the Sedifoliagrey pigment and production of methoxymicareic acid. So far, it has been known from Finland and Great Britain (LAUNis et al., 2019).

Parmelia serrana is morphologically and chemically very similar to $P$. saxatilis; they differ only in the presence of fatty acids: protolichesterinic and/or lichesterinic. Our specimens contained the following lichen substances: atranorin, salazinic, consalazinic, lobaric, lichesterinic protolichesterinic. Parmelia serrana can also be confused with $P$. ernstiae, which can be recognised by its pruinose lobes, mainly dull upper surface and short pseudocyphellae (TsURYKAU et al., 2019; Ossowska et al., 2018). Parmelia serrana appears to be rather widely distributed; it is known from Europe (Hawksworth et al., 2011; Thell et al., 2011) and northern Africa (TsuryKau et al., 2019). In Belarus and Latvia, P. serrana is often found in old swampy black alder forests (YATSYNA, 2020). Notably, however, the group needs more profound studies, as a recent paper (CoRsie et al., 2019) has shown that chemical and morphological features are not entirely reliable in distinguishing $P$. serrana, $P$. ernstiae and $P$. saxatilis.

Thelocarpon laureri is considered to be dependent on human activity (KocOURKOVÁ-HoRÁKOvÁ, 1998). We found this species, however, at a site with minimal human impact. It is a natural pine bog forest with a large number of dead trees and decaying wood. Thelocarpon laureri is found in Europe, the Canary Islands and North America (Orange et al., 2009).

Sclerophora amabilis is similar to $S$. peronella, but differs in its ascospore size (5-6 $\mu \mathrm{m}$ in diam.) and taller ascomata (TiBeL, 1999). This species was found in North America and Europe: Denmark, Norway and Sweden (Tibell, 1999), Luxembourg (DiEDERICH et al., 2012), the Czech Republic (MALÍČEK et al., 2014), Russia (Muchnik \& Konoreva, 2017), Estonia (OJA et al., 2016) and Belarus (YATSYNA et al., 2019). In Praviršulio Tyrelis, we found it on the bark of a solitary hollow giant oak with a DBH of more than two meters.

Three species of the Red Data Book of Lithuania (Rašomavičıus, 2007) were found in Praviršulio Tyrelis: Cetrelia olivetorum, Cladonia parasitica, Hypotrachyna revoluta. Regarding the new taxonomy, Cetrelia olivetorum s. str. occurs in ten localities throughout the territory of Lithuania (MotIEJŪNAITE, 2016). C. olivetorum was found on an old horizontal trunk of Rhamnus cathartica. Cladonia parasitica was found on dead wood in the raised bog. Hypotrachyna revoluta was found in old black alder forest on branches of Picea abies.

Fourteen species of lichens were found in Praviršulio Tyrelis, which are considered as indicator species of the main forest habitats (Motiejūnaité 
et al., 2004). They are as follows: Bacidia arceutina, B. polychroa, Calicium viride, Cetrelia olivetorum, Chaenotheca brachypoda, C. chlorella, Cladonia parasitica, Hypotrachyna revoluta, Inoderma byssaceum, Micarea melaena, Microcalicium disseminatum, Pycnora praestabilis, Sclerophora amabilis and Zwackhia viridis.

\section{ACKNOWLEDGEMENTS}

The authors are sincerely grateful to Jurga Motiejūnaitè (Vilnius) for determination of certain species of lichens, including Micarea pseudomicrococca and Thelocarpon laureri. Anonymous reviewers are thanked for valuable comments and suggestions for the manuscript.

\section{REFERENCES}

Corsie E.I., Harrold P., Yahr R., 2019: No combination of morphological, ecological or chemical characters can reliably diagnose species in the Parmelia saxatilis aggregate in Scotland. - The Lichenologist, 51(2): 107-121.

Diederich P., Ertz D., Eichler M., Cezanne R., van den Boom P., Fischer E., Killmann D., van den Broeck D. \& Sérusiaux E., 2012: New or interesting lichens and lichenicolous fungi from Belgium, Luxembourg and northern France. XIV. - Bulletin de la Société des naturalistes luxembourgeois, 113: 95-115.

Gliwa B., 2008: Gewässer und Ortsnamen um Praviršulis, Litauen. - Vārds un tā pētīšanas aspekti XII(1): 76-83. - Liepāja.

Hawksworth D.L., Divakar P.K., Crespo A., Анті T., 2011: The checklist of parmelioid and similar lichens in Europe and some adjacent territories: additions and corrections. - The Lichenologist, 43(6): 639-645.

KocourkovÁ-Horáková J., 1998: Distribution and ecology of the genus Thelocarpon (Lecanorales, Thelocarpaceae) in the Czech Republic. - Czech Mycology, 50(4): 271-302.

Launis A., Pykälä J., van den Boom P., SéruSiaux E., Myllys L., 2019: Four new epiphytic species in the Micarea prasina group from Europe. - The Lichenologist, 51(1): 7-25.

Lawrey J.D., Diederich P., 2018: Lichenicolous fungi - worldwide checklist, including isolated cultures and sequences available. http://www.lichenicolous.net (accessed 1 Jan 2018).

Malíček J., Palice Z., Vondrak J., 2014: New lichen records and rediscoveries from the Czech Republic and Slovakia. - Herzogia, 27: 257-284.

Motiejūnaité J., 2011: Lichens and allied fungi from the Kamanos State Strict Nature Reserve (northern Lithuania). - Botanica Lithuanica, 17(2-3): 109-116.

Motiejūnaité J., 2016: Žiauberiškosios kerpès (Fungi lichenisati). Lietuvos grybai, 13(2). - Vilnius.

Motiejūnaité J., CZyżewska K., Cieśliński S., 2004: Lichens - indicators of old-growth forests in biocentres of Lithuania and NE Poland. - Botanica Lithuanica, 10(1): 59-74.

Muchnik E., Konoreva L., 2017: New and noteworthy records of lichens and allied fungi from central European Russia. - Herzogia, 30: 509-514.

Nordin A., Moberg R., Tønsberg T., Vitikainen O., Dalsätt Å., Myrdal M., Snitting D., Ekman S., 2011: Santesson's checklist of Fennoscandian lichen-forming and lichenicolous fungi. Ver. 29 April 2011. http://130.238.83.220/santesson/home.php (accessed 25 Feb 2020).

Oja E., Gerasimova J., Suija A., Lõhmus P., RandLANE T., 2016: New Estonian records and amendments: Lichenized fungi. - Folia Cryptogamica Estonica, 53: 123-126.

Orange A., James P.W., White F.J., 2001: Microchemical methods for the identification of lichens. - London.

Orange A., Watson M.F., James P.W., Moore D.M., 2009: Thelocarpon Nyl. - In: Sмith C.W., Aptroot A., Coppins B.J., Fletcher A., Gilbert O.L., James P.W., Wolseley P.A. (eds), The Lichens of Great Britain and Ireland. The British Lichen Society, The Natural History Museum: 884-888. London.

Ossowska E., Guzow-Krzemińska B., Dudek M., Oset M., Kukwa M., 2018: Evaluation of diagnostic chemical and morphological characters in five Parmelia species (Parmeliaceae, lichenized Ascomycota) with special emphasis on the thallus pruinosity. - Phytotaxa, 383(2): 165-180.

RašomaviČıus V. (red.), 2007: Lietuvos raudonoji knyga. - Vilnius.

Stukonis V., 2009: Praviršulio botaninio-zoologin- 
io draustinio induočių augalų sąrašas. - In: ŠešKauskaité D., Gliwa B. (eds), Praviršulis: 42-64. - Kaunas.

Stukonis V., 2009a: Samanos. - In: ŠeŠKAuSKaITÉ D., Gliwa B. (eds), Praviršulis: 42-64. - Kaunas.

Thell A., Thor G., Ahti T., 2011: Parmelia Ach. In: Thell A., Moberg R. (eds), Nordic lichen flora. Nordic Lichen Society, 4: 83-90. - Göteborg. Tibel L., 1999: Calicioid lichens and fungi. - In: Ahti T., Jørgensen P.M., Kristinsson H., Moberg R., Søchting U., Thor G. (eds), Nordic lichen flo- ra. Nordic Lichen Society, 1: 20-71. - Uddevalla. Tsurykau A., Bely P., Golubkov V., Persson P.-E., Thell A., 2019: The lichen genus Parmelia (Parmeliaceae, Ascomycota) in Belarus. - Herzogia, 32: 375-384.

Yatsyna A.P., 2020: The lichen genus Parmelia Ach. in Belarus. - Diversity of plant world, 1(4): 5-16. [In Russian]

Yatsyna A.P., Golubkov V.V., Gimel'brant D.E., Konoreva L.A., Kuznetsova E.S., ČesnoKov S.V., 2019: Flora Belorusi. Lishajniki, 1. Minsk. [In Russian]

\title{
KERPĖS IR SU JOMIS SUSIJĘ GRYBAI PRAVIRŠULIO TYRELIO BOTANINIAME-ZO- OLOGINIAME DRAUSTINYJE
}

\author{
Aleksandr Yatsyna, Vaclovas Stukonis, Bernd Gliwa
}

\section{Santrauka}

Straipsnyje pateikiami ir aptariami kerpių ir su jomis susijusių grybų inventorizacijos duomenys Praviršulio tyrelio botaniniame-zoologiniame draustinyje. Iš viso inventorizuotos 199 rūšys (183 kerpès, aštuoni lichenizuoti ir aštuoni nelichenizuoti grybai). Pirmą kartą Lietuvoje identifikuotos keturios kerpių rūšys: Micarea pseudomicrococca, Parmelia serrana, Thelocarpon laureri ir Sclerophora amabilis. Rastos trys Lietuvos raudonosios knygos rūšys: žalsvoji kežytė, Cetrelia olivetorum, parazitinè šiurè, Cladonia parasitica ir alksnine hipotrachina, $\mathrm{Hy}$ potrachyna revoluta. 